\title{
Stratum Conjunctum
}

National Cancer Institute

\section{Source}

National Cancer Institute. Stratum Conjunctum. NCI Thesaurus. Code C33624.

A compact sublayer of stratum corneum in the epidermis. 